\title{
PEMETAAN KASUS DBD BERDASARKAN KONDISI LINGKUNGAN DI WILAYAH KERJA PUSKESMAS PRAMBON NGANJUK
}

Mapping Dbd Case Based On Environmental Conditions In Prambon Health Center Area Nganjuk

Riris Handini ${ }^{1}$, Nur Haidah ${ }^{2}$

${ }^{1}$ Poltekkes Kemenkes Surabaya

2 Poltekkes Kemenkes Makassar

*Email : nurhaidah2@gmail.com

\section{ABSTRAK}

According to Prambon Health Center data of 2017, the victims of DBD, DD and DSS in Prambon Health Center reached 20 people, with the $A B J$ value was $84,15 \%$. The aim of the research was to describe the distribution of the drop DBD case then mapping physical, biology and social environment in radius $100 \mathrm{~m}$ area from the drop of DBD case at Prambon Health Center, Nganjuk 2018. This research based on the characteristic include into descriptive research. Data collection was gathered using observantion villager houses in radius 100 meters from the case. Population data for this research was 238 houses that was spread in 11 drops of DBD case at 7 villages in Prambon Health Center area, Nganjuk. Data obtained were being analyzed in the form of map and descriptive. The result showed that mapping physical environment based on DBD case consist the behavior of deplete the water container was 131 houses (55,04\%), then people who didn't have the cover of water container was 221 houses (92,85\%). Mapping biology environment based on DBD case consist the house that positive of larva was 68 houses (28,57\%), then ABJ value in 7 villages of Prambon Health Center was under $95 \%$ that means out of the standart. Mapping social environment based on DBD case consist people who did't ever get information was 23 houses (9,66\%) then people who have habit hang clothes was 191 houses (80,25\%). From the study is recommended to optimizing implementation surveilans epidemiology of DBD case program by aprproacing the environmental, mapping endemic area of DBD by simple SIG program, increase the participation village cadre and public to keep the environmental clean by PSN and team working.

Keywords: DBD, Mapping, Environment conditions

\section{ABSTRAK}

Berdasarkan data dari Puskesmas Prambon (2017), Penderita DBD, DD dan DSS di wilayah kerja Puskesmas Prambon sebesar 20 orang, dengan ABJ sebesar $84,15 \%$. Tujuan penelitian ini yaitu menggambarkan persebaran titik kasus DBD serta pemetaan lingkungan fisik, biologi dan sosial pada area radius $100 \mathrm{~m}$ dari titik kasus DBD di wilayah kerja Puskesmas Prambon Kabupaten Nganjuk.Penelitian ini berdasarkan sifatnya termasuk pada penelitian deskriptif sederhana. Pengumpulan data dilakukan dengan observasi rumah warga yang berada di radius $100 \mathrm{~m}$ dari titik kasus DBD. Populasi dalam penelitian ini sebanyak 238 rumah yang tersebar pada 11 titik kasus DBD di 7 desa di Wilayah Kerja Puskesmas Prambon Kab. Nganjuk. Data yang diperoleh selanjutnya dianalisis dalam bentuk peta dan diskriptif. Hasil penelitian menunjukkan pemetaan lingkungan fisik berdasarkan kasus DBD yang terdiri dari perilaku tidak menguras ditemukan pada 131 rumah $(55,04 \%)$ sedangkan masyarakat yang tidak memiliki penutup kontainer yaitu 221 rumah $(92,85 \%)$. Pemetaan lingkungan biologi berdasarkan kasus DBD yang terdiri dari rumah positif jentik ditemukan pada 68 rumah $(28,57 \%)$ sedangkan ABJ 7 desa berada dibawah $95 \%$ yang berarti berada diluar standar. Pemetaan lingkungan sosial berdasarkan kasus DBD terdiri dari masyarakat yang belum mendapat penyuluhan ditemukan pada 23 rumah $(9,66 \%)$ sedangkan masyarakat yang memiliki kebiasaan menggantung pakaian yaitu 191 rumah $(80,25 \%)$. Disarankan perlu adanya pengoptimalan pelaksanaan program surveilans epidemiologi penyakit DBD dengan pendekatan lingkungan, melakukan pemetaan daerah endemik DBD dengan program SIG secara sederhana, meningkatan partisipasi kader desa dan masyarakat untuk menjaga lingkungan bersih dengan PSN dan kerja bakti.

Kata kunci : DBD, Pemetaan, Kondisi Lingkungan.

\section{PENDAHULUAN}

Menurut Profil Kesehatan Provinsi Jawa Timur tahun 2015, angka kesakitan DBD tahun 2015, di beberapa kabupaten/kota terjadi peningkatan jumlah penderita DBD dibandingkan sebelumnya. Insiden rate untuk Kabupaten Nganjuk pada tahun 2015 sebesar 33\%. Target Case Fatality Rate Jatim adalah kurang dari 1\%, namun tahun 2015 CFR Jatim mencapai $1,37 \%$. Selain itu terdapat 18 kabupaten/kota dengan CFR melebihi 1\%. CFR Kabupaten Nganjuk pada tahun 2015 mencapai 2,6\% .

Berdasarkan data dari Puskesmas Prambon (2017), pada tahun 2016 penderita DBD, DD dan DSS di wilayah kerja Puskesmas Prambon sebesar 42 orang, dengan penderita khusus DBD sebanyak 28 orang. Sedangkan pada tahun 2017 penderita DBD, DD dan DSS mencapai 20 orang, dengan penderita khusus DBD sebanyak 12 orang. Dari hasil pemantauan jentik berkala (PJB) pada tahun 2017, angka bebas jentik (ABJ) di Kecamatan Prambon adalah $84,15 \%$.

Pada prinsipnya pola dan persebaran penyakit mudah diamati berdasarkan usia, area geografis, komunitas dan sebagainya. Prosedur pengumpulan data secara manual dapat digantikan dengan digitalisasi yang lebih cepat, akurat dan hemat biaya. SIG dapat memberikan sistem terpadu secara spasial dalam memetakan, memantau kejadian penyakit menular, menganalisa lokasi rentan, menganalisa faktor-faktor lingkungan, perilaku masyarakat dan lain-lain. (Sri, 2009:158-159) 
Tujuan umum dalam penelitian ini adalah untuk menggambarkan pemetaan kasus DBD berdasarkan kondisi lingkungan di wilayah kerja Puskesmas Prambon Kabupaten Nganjuk. Sedangkan tujuan khusus dari penelitian ini adalah: Menggambarkan persebaran titik kasus DBD di wilayah kerja Puskesmas Prambon, dan menggambarkan pemetaan lingkungan fisik, bioloi dan sosial pada area radius $100 \mathrm{~m}$ dari titik kasus DBD di wilayah kerja Puskesmas Prambon Kab. Nganjuk

\section{METODE PENELITIAN}

Penelitian ini dilakukan secara deskriptif sederhana. Pengumpulan data dilakukan dengan observasi rumah warga di radius 100 $\mathrm{m}$ dari titik kasus DBD. Populasi dalam penelitian ini sebanyak 238 rumah yang tersebar pada 11 titik kasus DBD di 7 desa di Wilayah Kerja Puskesmas Prambon Kab. Nganjuk pada Januari-Maret 2018. Data yang diperoleh selanjutnya dianalisis dalam bentuk peta dan diskriptif menggunakan aplikasi SIG.

\section{HASIL DAN PEMBAHASAN}

1. Distribusi kejadian penyakit DBD

Kasus Demam Berdarah Dengue (DBD) bulan Januari sampai Maret 2018 di wilayah kerja Puskesmas Prambon Kabupaten Nganjuk sebesar 11 kasus.

Dari sebelas kasus, delapan orang berusia dibawah lima belas tahun. Lima kasus DBD terjadi pada bulan Januari. Distribusi kejadian penyakit DBD tersebar di 7 desa di wilayah Kerja Puskesmas Prambon. Desa dengan kasus DBD tertinggi yaitu Desa Baleturi. Di Desa Baleturi terdapat tiga titik kasus DBD yaitu Desa Baleturi RT 29/ RW 13, Desa Baleturi RT 13/ RW 06 dan Desa Baleturi RT 25/ RW 12.

2. Distribusi kejadian DBD berdasarkan Faktor Lingkungan Fisik

a. Distribusi Frekuensi Pengurasan Tempat Penampungan Air (TPA)

Berdasarkan hasil survey kasus DBD dengan lingkungan radius seratus meter, didapat hasil yaitu dari 238 rumah terdapat 131 rumah $(55,04 \%)$ tidak melakukan pengurasan minimal 1 kali seminggu secara rutin. Kemudian 107 rumah $(44,95 \%)$ melakukan pengurasan minimal 1 kali seminggu secara rutin.
Berdasarkan gambar 1. diketahui bahwa warna merah menunjukkan perilaku tidak menguras dengan persentase $66,67 \%-76 \%$ yaitu Desa Sanggrahan dan Desa Tegaron. Warna kuning menunjukkan perilaku tidak menguras dengan persentase 33,33\%-66,67\% yaitu Desa Sonoageng, Desa Watudandang dan Desa Mojoagung. Warna hijau menunjukkan perilaku tidak menguras dengan persentase 0\%-33,33\% yaitu Desa Kurungrejo dan Desa Baleturi.

Dari 7 desa berdasarkan persebaran titik kasus DBD, desa dengan rumah terbanyak yang tidak melakukan pengurasan minimal 1 kali seminggu secara rutin yaitu Desa Sanggrahan di RT 12/ RW 2 dan Desa Tegaron di RT 4/ RW 4.

Di Desa Sanggrahan RT 12/ RW 2 sebanyak 30 dari 40 rumah $(75 \%)$ tidak menguras minimal 1 kali seminggu secara rutin. Jumlah kasus DBD yang menjangkit sebanyak 2 kasus. Untuk Desa Tegaron RT 4/ RW 4 sebanyak 18 dari 25 rumah (72\%) tidak menguras minimal 1 kali seminggu secara rutin. Jumlah kasus DBD sebanyak 1 kasus.

Mayoritas rumah di Desa Sanggarahan dan Tegaron memiliki tempat penampungan air yang besar. Namun kedua desa tersebut bukan daerah sulit air. Untuk menguras bak mandi, memerlukan waktu dan tenaga yang cukup banyak. Hal tersebut juga dipengaruhi kesibukan pemilik rumah yang mengaku bekerja sebagai petani sehingga tidak sempat menguras bak penampungan air seminggu sekali secara rutin.

\section{b. Distribusi Ketersediaan Penutup Kontainer Air}

Berdasarkan hasil survey titik kasus DBD dengan lingkungan radius seratus meter, didapat hasil yaitu dari 238 terdapat 221 rumah $(92,85 \%)$ tidak mempunyai penutup kontainer air dan 17 rumah (7,14\%) mempunyai penutup kontainer air.

Perbandingan Persentase Ketersediaan Penutup Kontainer Air berdasarkan Kasus DBD dapat dilihat pada grafik gambar 2

Berdasarkan gambar 2. diketahui bahwa warna merah menunjukkan rumah tidak memiliki penutup kontainer air dengan persentase 93,33\%-100\% yaitu Desa Sonoageng, Desa Sanggrahan dan Desa Tegaron. Warna kuning menunjukkan rumah tidak memiliki penutup kontainer air dengan persentase 87,09\%-93,33\% yaitu Desa Watudandang dan Desa Mojoagung. Warna hijau menunjukkan rumah tidak memiliki penutup kontainer air dengan persentase 0\%-87,09\% yaitu Desa Kurungrejo dan Desa Baleturi 
Dari 7 desa berdasarkan persebaran titik kasus DBD, desa dengan rumah terbanyak yang tidak mempunyai penutup kontainer air yaitu Desa Sonoageng di Dusun Waung RT 23/ RW 6, Desa Sanggrahan di RT 12/ RW 2 dan Desa Tegaron di RT 4/ RW 4.

Di Desa Sonoageng Dusun Waung RT 23/ RW 6 sebesar 23 dari 23 rumah (100\%) tidak ada tutup kontainer air dengan jumlah kasus DBD sebanyak 1 kasus. Desa Sanggrahan RT 12/ RW 2 sebanyak 40 dari 40 rumah (100\%) tidak mempunyai penutup kontainer air. Jumlah kasus DBD yang menjangkit sebanyak 2 kasus. Desa Tegaron sebanyak 25 dari 25 rumah (100\%) tidak ada tutup kontainer air dengan jumlah kasus sebanyak 1 kasus.

Banyak masayakat yang membiarkan tempat penampungan air (bak kamar mandi dan gentong) terbuka. Tidak adanya tutup pada kontainer penampungan air dapat menyebabkan hinggapnya nyamuk yang akhirnya bertelur dan tumbuh jentik nyamuk, sehingga dapat menimbulkan kasus DBD dan dapat memperluas area penularan DBD

\section{Distribusi kejadian DBD berdasarkan Faktor Lingkungan Biologi \\ Distribusi Keberadaan Jentik}

Berdasarkan hasil survey titik kasus DBD dengan lingkungan radius seratus meter di wilayah kerja Puskesmas Prambon Kab. Nganjuk pada Januari-Maret 2018, didapat hasil yaitu dari 238 rumah terdapat 68 rumah $(28,57 \%)$ ditemukan jentik nyamuk dan 170 rumah $(71,42 \%)$ tidak ditemukan jentik nyamuk.

Dari 7 desa berdasarkan persebaran titik kasus DBD di wilayah kerja Puskesmas Prambon Kab. Nganjuk, desa dengan rumah terbanyak yang ditemukan jentik yaitu Desa Watudandang di RT 1/ RW 16 dan di RT 2/ RW 7, Desa Sanggrahan di RT 12/ RW 2 dan Desa Mojoagung di RT 1/ RW 1.

Desa Watudandang sebanyak 17 dari 52 rumah (32,69\%) positif jentik. Jumlah kasus DBD sebanyak 2 kasus. Desa Sanggrahan sebanyak 13 dari 40 rumah $(32,50 \%)$ positif jentik. Jumlah kasus DBD sebanyak 2 kasus. Desa Mojoagung sebanyak 5 dari 15 rumah $(33,33 \%)$ positif jentik. Jumlah kasus sebanyak 1 kasus.

Mayoritas masyarakat di Desa Sanggrahan memiliki bak penampungan air yang besar dan kadang ditemukan jentik. Namun daerah Sanggrahan bukan merupakan daerah sulit air. Perilaku pengurasan yang buruk menyebabkan menyebabkan jentik dapat tumbuh dan bertambah banyak. Jentik juga ditemukan di area tempat penampungan air di WC. Masyarakat mengaku jika jarang menguras bak WC karena ukurannya kecil dan akan segera habis, namun waktu pengurasan yang tidak menentu justru menyebabkan jentik dapat berkembang. Selain di dalam rumah, jentik juga ditemukan di luar rumah (di genangan air dalam ban dan kaleng cat).

\section{b Distribusi Angka Bebas Jentik}

Berdasarkan hasil survey titik kasus DBD dengan lingkungan radius seratus meter di wilayah kerja Puskesmas Prambon Kab. Nganjuk pada Januari-Maret 2018, didapat hasil yaitu dari tujuh desa yang diperiksa semua desa memiliki ABJ dibawah 95\%, yang berarti tidak memenuhi standar.

1) Perbandingan Persentase Keberadaan Jentik berdasarkan Kasus DBD di Wilayah Puskesmas Prambon Kab. Nganjuk pada Januari-Maret 2018

Berdasarkan gambar 3, diketahui bahwa warna merah menunjukkan rumah positif jentik dengan persentase $28,57 \%-33,33 \%$ yaitu Desa Watudandang, Desa Sanggrahan dan Desa Mojoagung. Warna kuning menunjukkan rumah positif jentik dengan persentase 24,19\%$28,57 \%$ yaitu Desa Kurungrejo dan Desa Tegaron. Warna hijau menunjukkan rumah positif jentik dengan persentase 0\%-24,19\% yaitu Desa Sonoageng dan Desa Baleturi.

Dari 7 desa berdasarkan persebaran titik kasus DBD di wilayah kerja Puskesmas Prambon Kab. Nganjuk, desa dengan ABJ terendah yaitu Desa Watudandang di RT 1/ RW 16 dan di RT 2/RW7,Desa Sanggrahan di RT12/ RW2 dan Desa Mojoagung di RT1/RW 1.

Desa Watudandang memiliki nilai $\mathrm{ABJ}$ sebesar $67,31 \%$ dengan jumlah kasus DBD sebanyak 2 kasus. Desa Sanggrahan memiliki nilai ABJ sebesar $67,50 \%$ dengan jumlah kasus DBD sebanyak 2 kasus. Desa Mojoagung memiliki nilai $A B J$ sebesar $66,67 \%$ dengan jumlah kasus sebanyak 1 kasus.

Rendahnya nilai ABJ di Desa Watudandang di RT 1/ RW 16 dan di RT 2/ RW 7, Desa Sanggrahan di RT 12/ RW 2 dan Desa Mojoagung di RT 1/ RW 1 menunjukkan bahwa masyarakat masih belum sadar akan perilaku hidup bersih dan sehat dengan menerapkan kegiatan PSN 
Jurnal Sulolipu : Media Komunikasi Sivitas Akademika dan Masyarakat

Vol. 21 No.2 2021

e-issn : 2622-6960, p-issn : 0854-624X

mandiri. Sehingga masih banyak ditemukan adanya jentik yang berdampak pada nilai $A B J$ yang rendah.

Persebaran ABJ dapat dilihat pada gambar 4

Berdasarkan gambar 4,diketahui bahwa warna merah menunjukkan nilai $\mathrm{ABJ}(0 \%$ 67,50\%) yaitu Desa Watudandang, Desa Sanggrahan dan Desa Mojoagung. Warna kuning menunjukkan nilai ABJ $(67,50 \%$ 72\%) yaitu Desa Kurungrejo dan Desa Tegaron. Warna hijau menunjukkan nilai ABJ (72\%-78,26\%) yaitu Desa Sonoageng dan Desa Baleturi.

\section{Distribusi kejadian DBD berdasarkan Faktor Lingkungan Sosial}

\section{a. Distribusi Penyuluhan pada Masyarakat}

Berdasarkan hasil survey titik kasus DBD dengan lingkungan radius seratus meter, didapat hasil yaitu dari 238 rumah terdapat 215 rumah $(90,33 \%)$ pernah mendapatkan penyuluhan dan 23 rumah $(9,66 \%)$ belum pernah mendapatkan penyuluhan.

Dari 7 desa berdasarkan persebaran titik kasus DBD, desa dengan rumah terbanyak yang yang belum mendapat penyuluhan yaitu Desa Watudandang. Desa Watudandang sebanyak 15 dari 52 rumah $(28,85 \%)$ tidak mendapat penyuluhan dengan jumlah kasus DBD sebanyak 2 kasus.

Hasil perbandingan persentase pengalaman mendapat penyuluhan berdasarkan kasus DBD menunjukkan bahwa Desa Baleturi paling banyak terjangkit kasus DBD yaitu tiga kasus yang tersebar di RT 13/ RW 6, RT 25/ RW 12 dan RT 29/ RW 13. Tingginya kasus DBD didukung dengan pengalaman masyarakat Desa Baleturi di RT 13/ RW 6, RT 25/ RW 12 dan RT 29/ RW 13 yang sebagian belum mendapat penyuluhan yaitu sebesar 5 dari 62 rumah (8,06\%). Hal ini menunjukkan bahwa penyuluhan yang dilakukan tidak merata di masyarakat. Akibatnya pengetahuan masyarakat tentang DBD juga tidak sama. Mayoritas desa-desa di wilayah kerja Puskesmas Prambon, melakukan penyuluhan pada hari Jum'at bersamaan dengan pemantauan jentik berkala. Meski sebagian besar sudah dilakukan penyuluhan, namun hal tersebut ternyata tidak terlalu mempengaruhi perilaku masyarakat terkait PSN b. Distribusi Kebiasaan Menggantung Pakaian pada Masyarakat

Berdasarkan hasil survey titik kasus DBD dengan lingkungan radius seratus meter di wilayah kerja Puskesmas Prambon Kab. Nganjuk pada Januari-Maret 2018, didapat hasil yaitu dari 238 rumah terdapat 191 rumah $(80,25 \%)$ menggantung pakaian dan 47 rumah $(19,74 \%)$ tidak menggantung pakaian.

Dari 7 desa berdasarkan persebaran titik kasus DBD, desa dengan rumah terbanyak yang yang memiliki kebiasaan menggantung pakaian yaitu Desa Watudandang. Desa Watudandang sebanyak 45 dari 52 rumah (86,54\%) menggantung pakaian dengan jumlah kasus DBD sebanyak 2 kasus.

Hasil perbandingan persentase kebiasaan menggantung pakaian berdasarkan kasus DBD, menunjukkan bahwa Desa Baleturi paling banyak terjangkit kasus DBD yaitu tiga kasus yang tersebar di RT 13/ RW 6, RT 25/ RW 12 dan RT 29/ RW 13. Tingginya kasus DBD didukung dengan perilaku masyarakat Desa Baleturi di RT 13/ RW 6, RT 25/ RW 12 dan RT 29/ RW 13 yang memiliki kebiasaan menggantung pakaian yaitu sebesar 49 dari 62 rumah $(79,03 \%)$.

\section{KESIMPULAN}

1. Distribusi kejadian penyakit DBD di wilayah kerja Puskesmas Prambon tersebar di 7 wilayah dengan 11 titik kasus. Desa dengan kasus DBD terbanyak yaitu Desa Baleturi sebanyak 3 kasus.

2. Pemetaan lingkungan fisik terdiri dari Perilaku tidak menguras ditemukan pada 131 rumah $(55,04 \%)$ sedangkan masyarakat yang tidak memiliki penutup kontainer yaitu 221 rumah (92,85\%)

3. Pemetaan lingkungan biologi terdiri dari rumah positif jentik ditemukan pada 68 rumah $(28,57 \%)$ sedangkan ABJ 7 desa berada dibawah $95 \%$ yang berarti berada diluar standar.

Pemetaan lingkungan sosial terdiri dari masyarakat yang belum mendapat penyuluhan ditemukan pada 23 rumah $(9,66 \%)$ sedangkan masyarakat yang memiliki kebiasaan menggantung pakaian yaitu 191 rumah $(80,25 \%)$ 
Jurnal Sulolipu : Media Komunikasi Sivitas Akademika dan Masyarakat

Vol. 21 No.2 2021

e-issn : 2622-6960, p-issn : 0854-624X

\section{SARAN}

Adapun saran yang dapat diberikan adalah :

a. Melakukan pemetaan daerah endemik DBD di seluruh wilayah kerja Puskesmas Prambon Kab Nganjuk dengan SIG secara sederhana.

b. Melibatkan dan memantau kinerja kader desa dalam upaya pemerataan penyuluhan kesehatan secara periodik. c. Meningkatkan partisipasi masyarakat untuk menjaga lingkungan bersih dengan PSN secara rutin minimal seminggu sekali dan kerja bakti.

d. Menambah pengetahuan masyarakat terhadap risiko bahaya lingkungan sebagai tempat perindukan nyamuk Aedes aegypti.

\section{DAFTAR PUSTAKA}

Ariani, Ayu Putri. 2016. Demam Berdarah Dengue. Yogyakarta: Nuha Medika

Eka, Widia Wati. 2009. Beberapa Faktor Yang Berhubungan Dengan Kejadian Demam Berdarah Dengue (DBD) Di Kelurahan Ploso Kecamatan PacitanTahun 2009 (SKRIPSI). Jakarta : Universitas Muhammadiyah Surakarta.

Indarto dan Faisol, Arif. 2012. Konsep Dasar Analisis Spasial. Yogyakarta : Penerbit Andi Irianto, koes.2015. Memahami Berbagai Macam Penyakit. Bandung: Alvabeta,cv

uliansyah dan Tri Baskoro. 2016. Analisis Pola Sebaran Demam Berdarah Dengue Terhadap Penggunaan Lahan Dengan Pendekatan Spasial Di KabupatenBanggai Provinsi Sulawesi Tengah Tahun 2011-2013. Journal of Information Systems for Public Health, 1 (1) : 47-54

Musyarifatun Farahiyah, Nurjazuli dan Onny Setiani. 2014. Analisis Spasial Faktor Lingkungan Dan Kejadian Dbd Di Kabupaten Demak. Bul. Penelit. Kesehat, 1 (42) : 25 - 36

Nadesul, Handrawan. 2016. Kiat Mengalahkan Demam Berdarah dan Virus Zika. Jakarta : PT. Kompas Media Nusantara.

Nurdiansah Sahrir, Hasanuddin Ishak dan Alimin Maidin. 2016. Pemetaan Karakteristik Lingkungan Dan Densitas Nyamuk Aedes aegypti Berdasarkan Status Endemisitas Dbd Di Kecamatan Kolaka. Jurnal JST Kesehatan, 1 I (6): 70 - 75

Peraturan Menteri Kesehatan Republik Indonesia Nomor 13 Tahun 2015 tentang Penyelenggaraan Pelayanan Kesehatan Lingkungan di Puskesmas

Peraturan Menteri Kesehatan Republik Indonesia Nomor 374 tahun 2010 tentang Pengendalian Vektor

Peraturan Menteri Kesehatan Republik Indonesia Nomor 50 tahun 2017 tentang Standar Baku Kesehatan Lingkungan Dan Persyaratan Kesehatan Untuk Vektor Dan Binatang Pembawa Penyakit Serta Pengendaliannya.

Pusat Data dan Surveilans Epidemiologi Kementerian Kesehatan RI. 2010. Buletin Jendela Epidemiologi. Jakarta. Sekapur Sirih

Putry, Mentari Rendy. 2013. Hubungan Faktor Perilaku Dan Faktor Lingkungan Dengan Keberadaan Larva Nyamuk Aedes aegypti Di Kelurahan Sawah Lama Tahun 2013 (SKRIPSI). Jakarta : Universitas Islam Negeri Syarif Hidayatullah

Ririh Yudhastuti dan Anny Vidiyani. 2005. Hubungan Kondisi Lingkungan, Kontainer, Dan Perilaku Masyarakat Dengan Keberadaan Jentik Nyamuk Aedes aegypti Di Daerah Endemis Demam Berdarah Dengue Surabaya. Jurnal Kesehatan Lingkungan, 2 (1) : 170182

Saepudin, Malik. 2011. Metodologi Penelitian Kesehatan Masyarakat. Jakarta : CV. Trans Info Media

Sitti Badrah dan Nurul Hidayah. 2011. Hubungan Antara Tempat Perindukan Nyamuk Aedes Aegypti Dengan Kasus Demam Berdarah Dengue Di Kelurahan Penajam Kecamatan Penajam Kabupaten Penajam Paser Utara. J. Trop. Pharm. Chem. 2011, 2 (1) : 154-160

Suryadi,Indrawan dan Hartoyo, G Manjela Eko. 2012. Panduan Aplikasi Sistem Informasi Geografs Tingkat Dasar. Balikpapan : Tropenbos International Indonesia Programme

Wahyuningsih, Fajriyatin. 2014. Analisis Spasial Kejadian Demam Berdarah Dengue di Wilayah Kerja Puskesmas Pengasinan Kota Bekasi Tahun 2011-2013 (SKRIPSI). Jakarta : Universitas Islam Negeri Syarif Hidayatullah

Yuli Yana dan Sri Ratna Rahayu. 2017. Analisis Spasial Faktor Lingkungan Dan Distribusi Kasus Demam Berdarah Dengue. Higeia Journal Of Public Health Research And Development. 1 (3) : 106-116 
Jurnal Sulolipu : Media Komunikasi Sivitas Akademika dan Masyarakat Vol. 21 No.2 2021

e-issn : 2622-6960, p-issn : 0854-624X

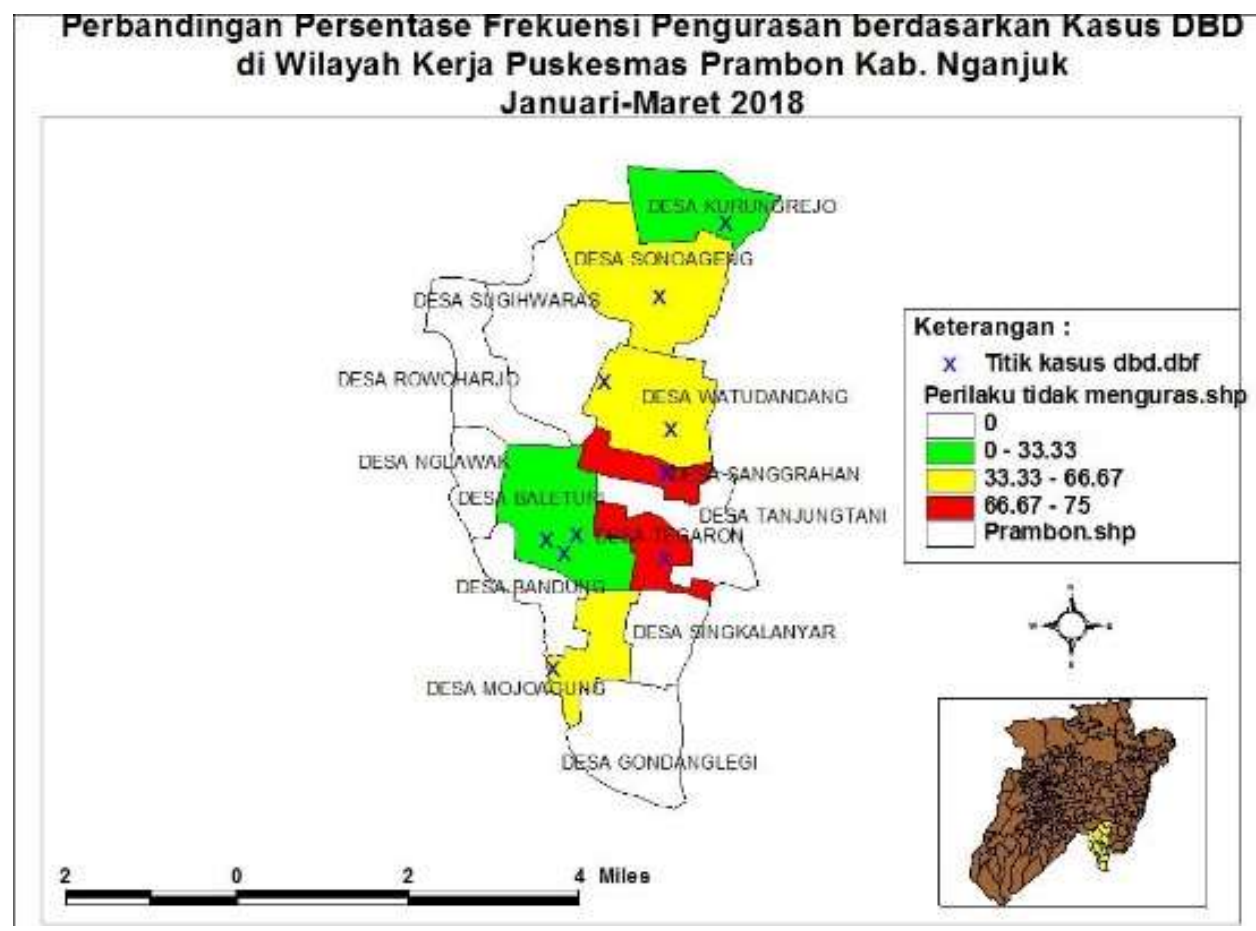

Gambar 1. Perbandingan persentase frekuensi pengurasan TPA

Tabel 1

Distribusi Frekuensi Pengurasan Tempat Penampungan Air

\begin{tabular}{cccc}
\hline No & Variabel & Jumlah & $(\%)$ \\
\hline 1 & Menguras benar dan teratur & 107 & 44,95 \\
2 & Tidak menguras & 131 & 55,04 \\
\hline & Jumlah & 238 & 100 \\
\hline
\end{tabular}

Sumber Data Primer 2018

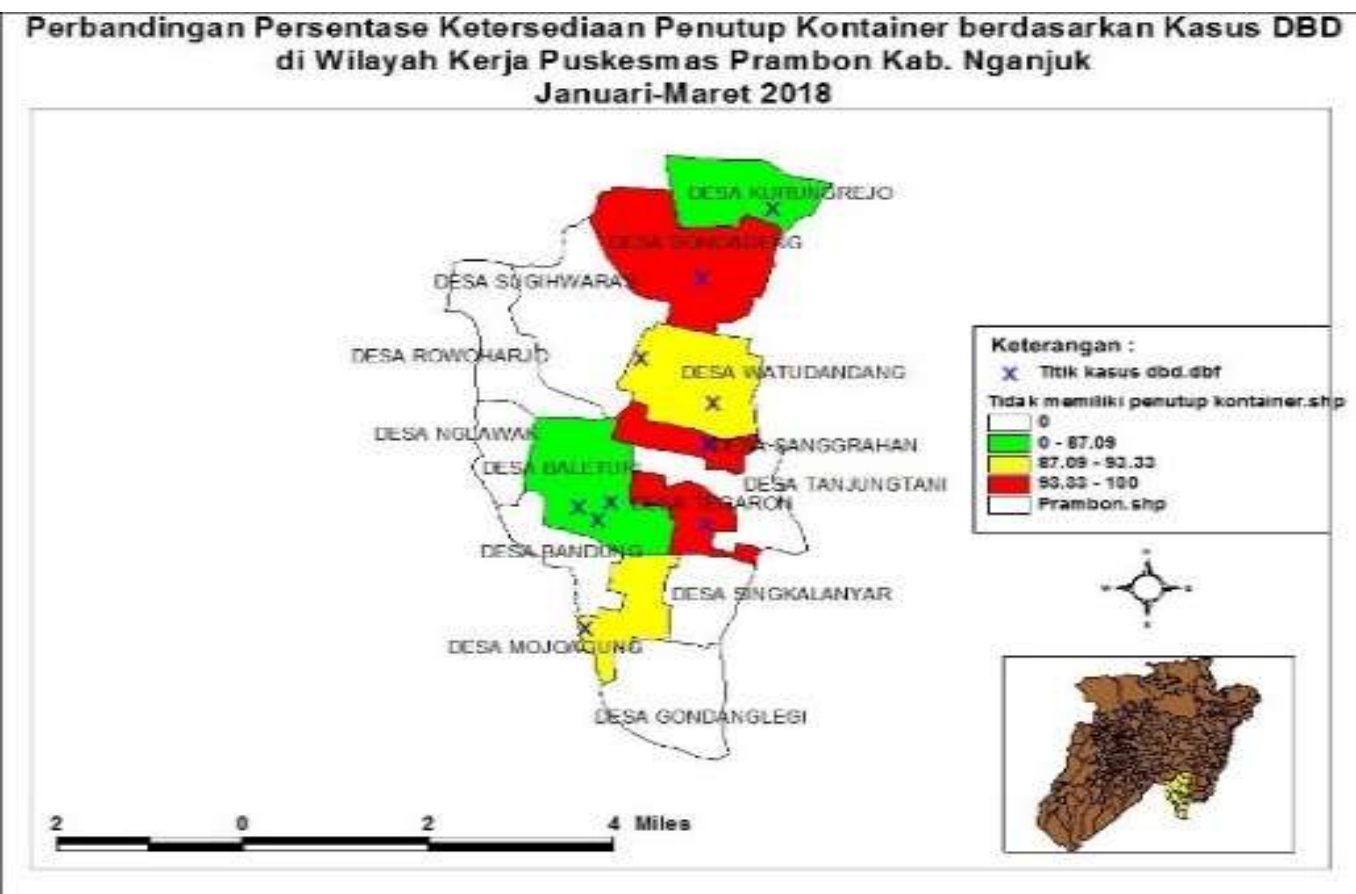


Jurnal Sulolipu : Media Komunikasi Sivitas Akademika dan Masyarakat Vol. 21 No.2 2021

e-issn : 2622-6960, p-issn : 0854-624X

Gambar2 Perbandingan Persentase Ketersediaan Penutup Kontainer Air

Tabel 2

Distribusi Ketersediaan Penutup Kontainer Air

\begin{tabular}{cccc}
\hline No & Variabel & Jumlah & $(\%)$ \\
\hline 1 & Ada penutup kontainer & 17 & 7,14 \\
2 & Tidak ada penutup kontainer & 221 & 92,86 \\
\hline & Jumlah & 238 & 100 \\
\hline
\end{tabular}

Sumber Data Primer 2018

Tabel 3

Distribusi Keberadaan Jentik Di Wilayah Puskesmas Prambon

Kab. Nganjuk januari-maret 2018

\begin{tabular}{cccc}
\hline No & Variabel & Jumlah & $(\%)$ \\
\hline 1 & Terdapat jentik & 68 & 28,57 \\
2 & Tidak terdapat jentik & 170 & 71,43 \\
\hline & Jumlah & 238 & 100 \\
\hline
\end{tabular}

Sumber Data Primer 2018

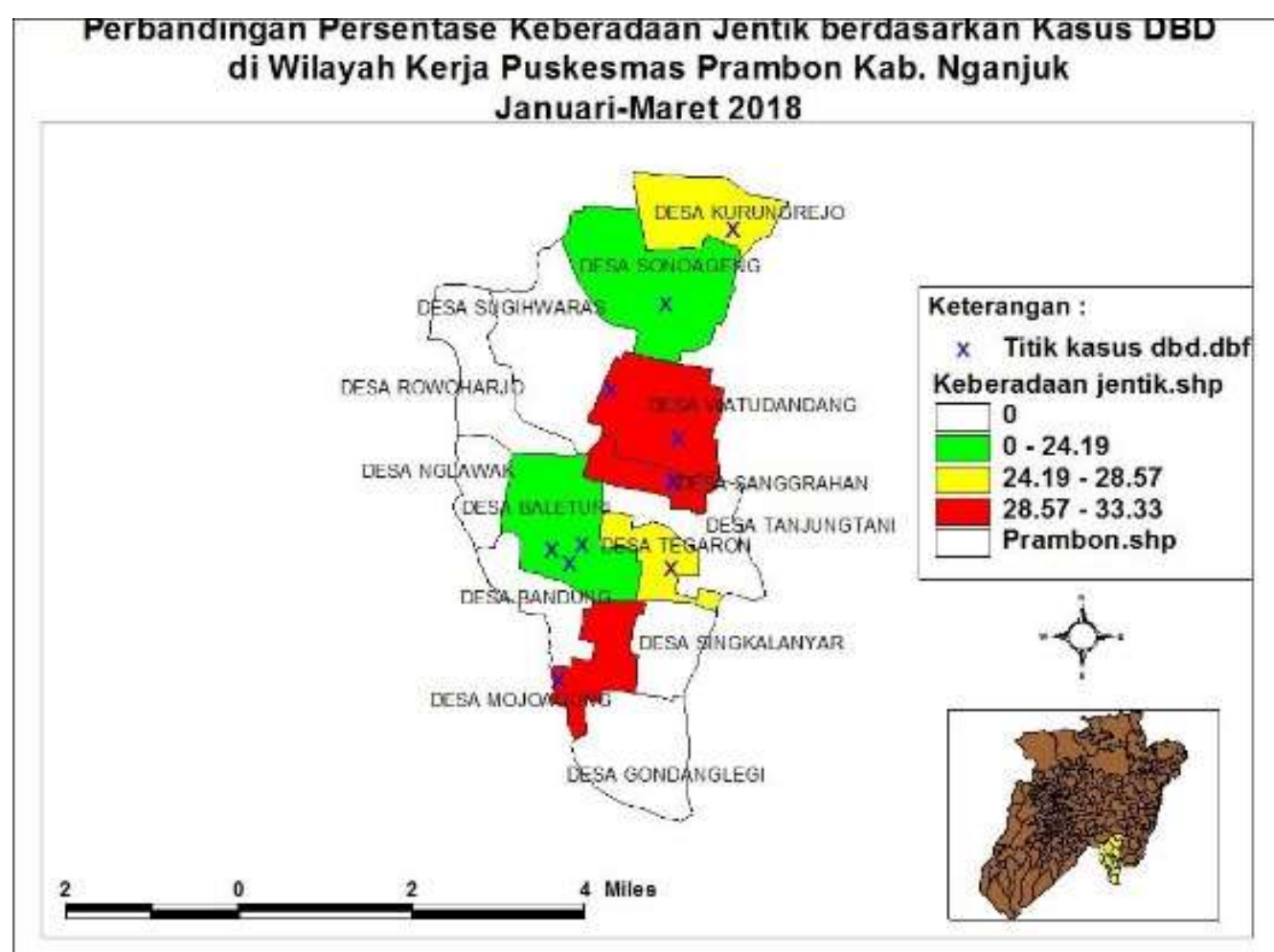

Gambar 3 Perbandingan Persentase Keberedaan Jentik 
Jurnal Sulolipu : Media Komunikasi Sivitas Akademika dan Masyarakat Vol. 21 No.2 2021

e-issn : 2622-6960, p-issn : 0854-624X

Tabel 4

Distribusi Angka Bebas Jentik Per Desa Berdasarkan Titik Kasus

\begin{tabular}{|c|c|c|c|}
\hline No & Variabel & Jumlah & $(\%)$ \\
\hline 1 & ABJ $<95 \%$ & 7 & 100 \\
\hline 2 & $A B J>95 \%$ & 0 & 0 \\
\hline & Jumlah & 7 & 100 \\
\hline
\end{tabular}

Sumber Data Primer 2018

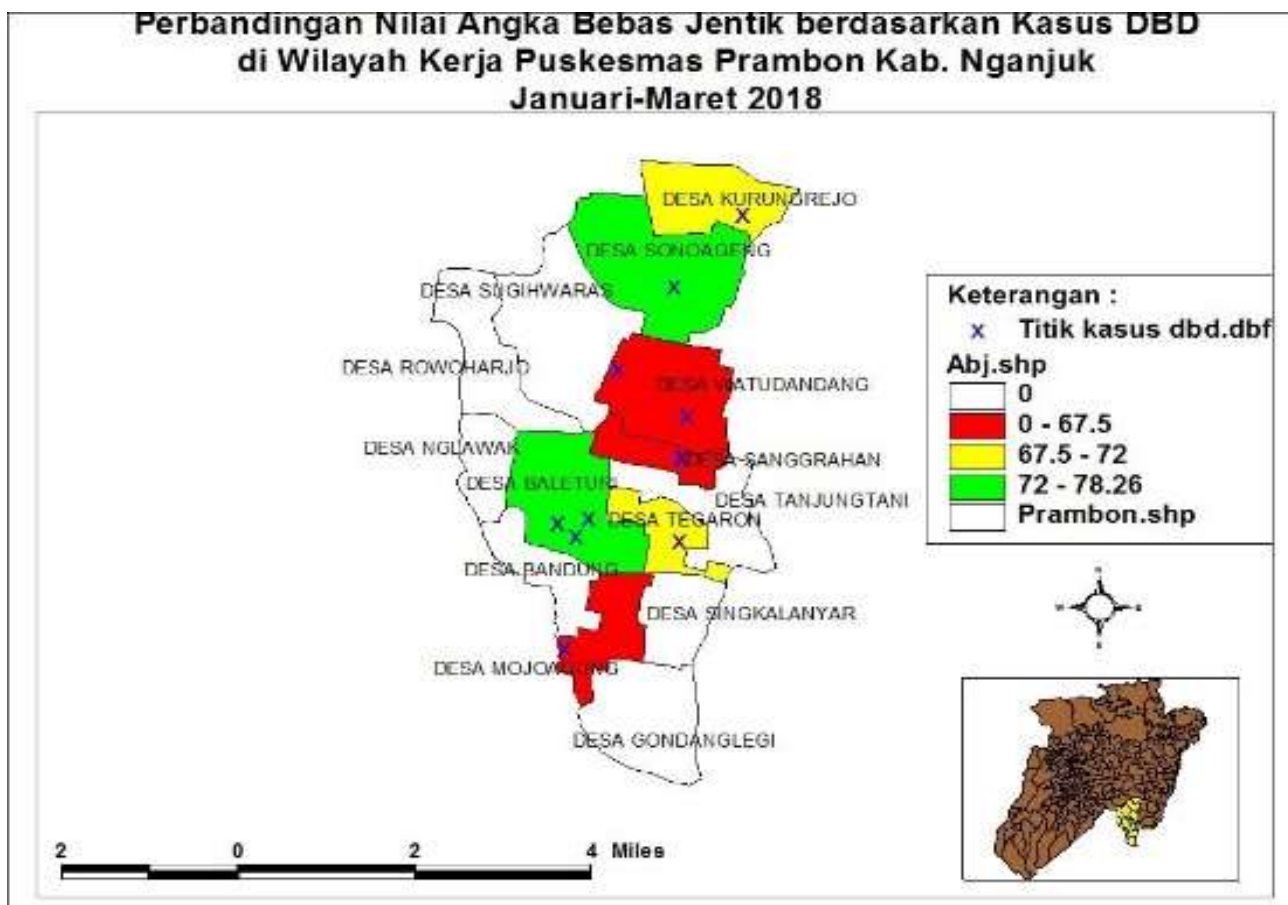

Gambar 4, Peta Distribusi Nilai ABJ

Tabel 5

Distribusi Penyuluhan Pada Masyarakat

\begin{tabular}{|c|c|c|c|}
\hline No & Variabel & Jumlah & $(\%)$ \\
\hline 1 & Mendapat penyuluhan & 215 & 90,34 \\
\hline 2 & Tidak mendapat penyuluhan & 23 & 9,66 \\
\hline & Jumlah & 238 & 100 \\
\hline
\end{tabular}

Sumber Data Primer 2018

Tabel 6

Distribusi Kebiasaan Menggantung Pakaian

\begin{tabular}{|c|c|c|c|}
\hline No & Variabel & Jumlah & (\%) \\
\hline 1 & Menggantung pakaian & 191 & 80,25 \\
\hline 2 & Tidak menggantung pakaian & 47 & 19,75 \\
\hline & Jumlah & 238 & 100 \\
\hline
\end{tabular}

Sumber Data Primer 2018 